\title{
FOOD PRICE, LOSSES AND LOGISTICS AFFECTING DIET DIVERSIFICATION AND FOOD SECURITY
}

\author{
Eduardo Botti Abbade \\ Doutor em Agronegócio \\ Universidade Federal de Santa Maria Santa Maria - RS - Brasil \\ eduardo.abbade@ufsm.br https://orcid.org/0000-0002-0552-0051
}

\begin{abstract}
This study aimed to investigate the impact of logistics performance, domestic food price, and food loss on diet diversification and depth of food deficit, as well as the impact of diet diversification and depth of food deficit on the prevalence of undernourishment worldwide. This investigation adopts a quantitative approach based on available data obtained from the Food and Agriculture Organization (FAO), the Global Food Security Index, and the World Bank Group. This study uses correlation analysis and multiple linear regression analysis as the analytical procedures. In a global perspective, evidence suggests that weak logistics performance tends to increase food loss, and domestic food price has a significant impact on diet diversification, as well as the domestic food price implies a significant increase in depth of food deficit in the world's populations. Food price is the factor that most impacts the prevalence of undernourishment, severely affecting diet diversification and depth of food deficit worldwide. Reducing food prices has the potential to promote greater diet diversification for populations worldwide, contributing to promote global food security. This study highlights the necessity to develop an improved and efficient global food system, capable of reducing food prices, promote a cleaner food production and deliver improved nutrition and health for world populations. This investigation sustains that food price severely impacts the prevalence of undernourishment, affecting diet diversification and depth of food deficit worldwide.
\end{abstract}

Key words: Food price. Food systems. Food waste. Malnutrition. Sustainable development. Undernourishment.

\section{PREÇO DOS ALIMENTOS, PERDAS E LOGÍSTICA AFETANDO A DIVERSIFICAÇÃO DIETÉTICA E A SEGURANÇA ALIMENTAR}

\section{RESUMO}

Este estudo objetivou investigar o impacto do desempenho logístico, preço dos alimentos e perda alimentar na diversificação dietética e profundidade do déficit alimentar, bem como o impacto da diversificação dietética e profundidade do déficit alimentar na prevalência de desnutrição nas nações mundiais. Esta investigação utiliza uma abordagem ecológica, com base nos dados obtidos na Organização para Agricultura e Alimentação (FAO), no Índice Global de Segurança Alimentar e no Banco Mundial. Este estudo utiliza análise de correlação e análise de regressão linear múltipla. As evidências sugerem que o fraco desempenho logístico tende a aumentar a perda de alimentos, e o preço dos alimentos domésticos tem um impacto significativo na diversificação dietética, assim como o preço dos alimentos implica em aumento significativo na profundidade do déficit alimentar nas populações mundiais. O preço dos alimentos é o fator que mais afeta a prevalência de desnutrição, afetando severamente a diversificação dietética e a profundidade do déficit alimentar no mundo. A redução dos preços dos alimentos tem potencial de promover maior diversificação dietética das populações mundiais, contribuindo para promover a segurança alimentar em âmbito global. Este estudo destaca a necessidade de se promover sistemas alimentares globais mais eficientes, capazes de reduzir os preços dos alimentos, promover uma produção mais limpa de alimentos e fornecer nutrição e saúde apropriadas para as populações do mundo. Esta investigação sustenta que o preço dos alimentos afeta severamente a prevalência de desnutrição, afetando a diversificação dietética e a profundidade do déficit alimentar em todo o mundo.

Palavras-chave: Desenvolvimento sustentável. Desperdício alimentar. Desnutrição. Preço dos alimentos. Sistemas alimentares. Subnutrição.

Data da submissão: 24/07/2020

Data de aceite: 01/10/2020 
Food price, losses and logistics affecting diet diversification and food security

\section{INTRODUCTION}

Despite world efforts in the fight against hunger and malnutrition, the number of undernourished people in the world has been rising since 2014, reaching an estimated 821 million (10.9\% of world's population) in 2017. Africa still presents the highest levels of food insecurity, affecting more than 256 million people (almost $21 \%$ of the population) (FAO, 2018b). Children are the most affected by undernutrition, and around $45 \%$ of deaths among children under 5 years are linked to undernutrition. It is known that optimizing nutrition early in life ensures the best possible start in life, with long-term benefits for individuals and societies, reducing future healthcare costs as well as promoting future conditions to enhance productivity and economic growth (WHO, 2018).

Promoting global food security is a challenge for all nations and means ensuring that all people have sufficient food purchasing conditions in terms of quantity and nutrition (Sen, 1981). The concept of food security is associated with four conditions - availability, adequate access, conditions of using foods and nutrients, and stability or sustainability for these dimensions over time (Barrett, 2010; FAO, 2008; Webb et al., 2006). Ensuring these conditions requires adequate coordination between agents working in food systems, as pre-harvest suppliers, producers, postharvest handlers, processors, and distributors, as well as consumers (Ingram, 2011).

Humankind faces the urgent problem of food loss and waste (FLW), a crucial issue that deserves attention, especially considering the urgent needs related to the growing food needs of the world's population (Parfitt et al., 2010). It is evidenced that about a third of all food produced worldwide is lost during the productive process or consumption (FAO, 2011). Converting the food loss into calories, the results show that for every four calories consumed, one is lost (Lipinski et al., 2013). Also, FLW has implications in the waste of important natural and economic resources, mostly associated with the main constructs of the water-energy-food nexus (Al-Ansari et al., 2017; Kibler et al., 2018; Zhang et al., 2018). Reducing FLW worldwide represents an essential strategy for increasing food security and reducing environmental pressures (Garcia-Herrero et al., 2018; Irani et al., 2018).

The FLW observed worldwide possibly is aggravated by logistics inefficiency and the high levels of domestic food prices. The logistics infrastructure and performance offers conditions to promote better physical access to food, and accessible domestic food prices promote conditions for economic access to food (Babu et al., 2014; Butcher et al., 2018). Earlier studies have clearly shown that adequate access to food, promoted through logistics performance and economic conditions, has strong implications for food security promotion worldwide (Abbade, 2017; Jedermann et al., 2014; Thyberg \& Tonjes, 2016).

Thus, proper access to food ensures that people are able to avail an adequate diet diversification, promoting access to nutrients from the main food groups (Nair et al., 2016). Also, adequate opportunity to obtain food possibly helps to reduce the depth of food deficit, promoting adequate access to the main macronutrients. The household dietary diversity score (HDDS) offers a measurement alternative to evaluate the diet diversification in a given population, since this indicator is measured considering the number of food groups consumed by one or more household members over a given reference period (Romeo et al., 2016). Moreover, several earlier studies presented evidence that household dietary diversity is associated with improved nutrient intake in developed and developing countries (Kennedy et al., 2007; M'Kaibi et al., 2017; Steyn et al., 2006), and that a lower HDDS can increase the potential risk for worsening of micronutrient deficiencies and child malnutrition (Thorne-Lyman et al., 2010).

Malnutrition is a multifaceted concept that encompass several dimensions related to food security, such as undernourishment, underweight, overweight, obesity, diet diversification, food deficit, and dietary intake. In addition, the coexistence of undernutrition along with overweight or obesity, or even with diet-related non-communicable diseases, defined as the double burden of malnutrition, highlights the complexity of the malnutrition concept (Delisle \& Batal, 2016; WHO,

Revista de Gestão Social e Ambiental - RGSA, São Paulo, v. 14, n. 3, p. 57-74, set./dez. 2020. 
2017). This investigation focuses on diet diversification, food deficit and undernourishment as dimensions of malnutrition.

Food price and economic access also play an important role in promoting food security. Considering the rising prices of food observed globally, projections presented by the FAO suggest that rising prices might lead a considerable amount of the world's population into extreme hunger (FAO, 2018b). With rising food prices and the policy responses to the these being inadequate, the population becomes more vulnerable to famine; and children, pregnant women and the elderly face the highest risk of malnutrition and death (Cornia et al., 2016). Indeed, earlier studies presented evidence that domestic food prices are seen as a determinant of child malnutrition (Cornia et al., 2016; Vellakkal et al., 2015).

Considering the arguments exposed here, this study aims to investigate the impact of logistics performance, domestic food price and food loss on diet diversification and depth of food deficit, as well as the impact of diet diversification and depth of food deficit on prevalence of undernourishment worldwide. The findings of this study should provide a better understanding of the relevant degree of the antecedent factors investigated (price and logistic performance) that possibly enhance FLW and interfere in the promotion of food security. Thus, this study provides evidence with the potential to assist in the design and implementation of public policies and initiatives in the private sector to promote better conditions to reduce the prevalence of undernourishment, as well as food and nutritional insecurity worldwide.

\section{METHOD}

This study was conducted in order to investigate the association between the main variables of the reference model presented in figure 1, considering the 10 hypotheses addressed.

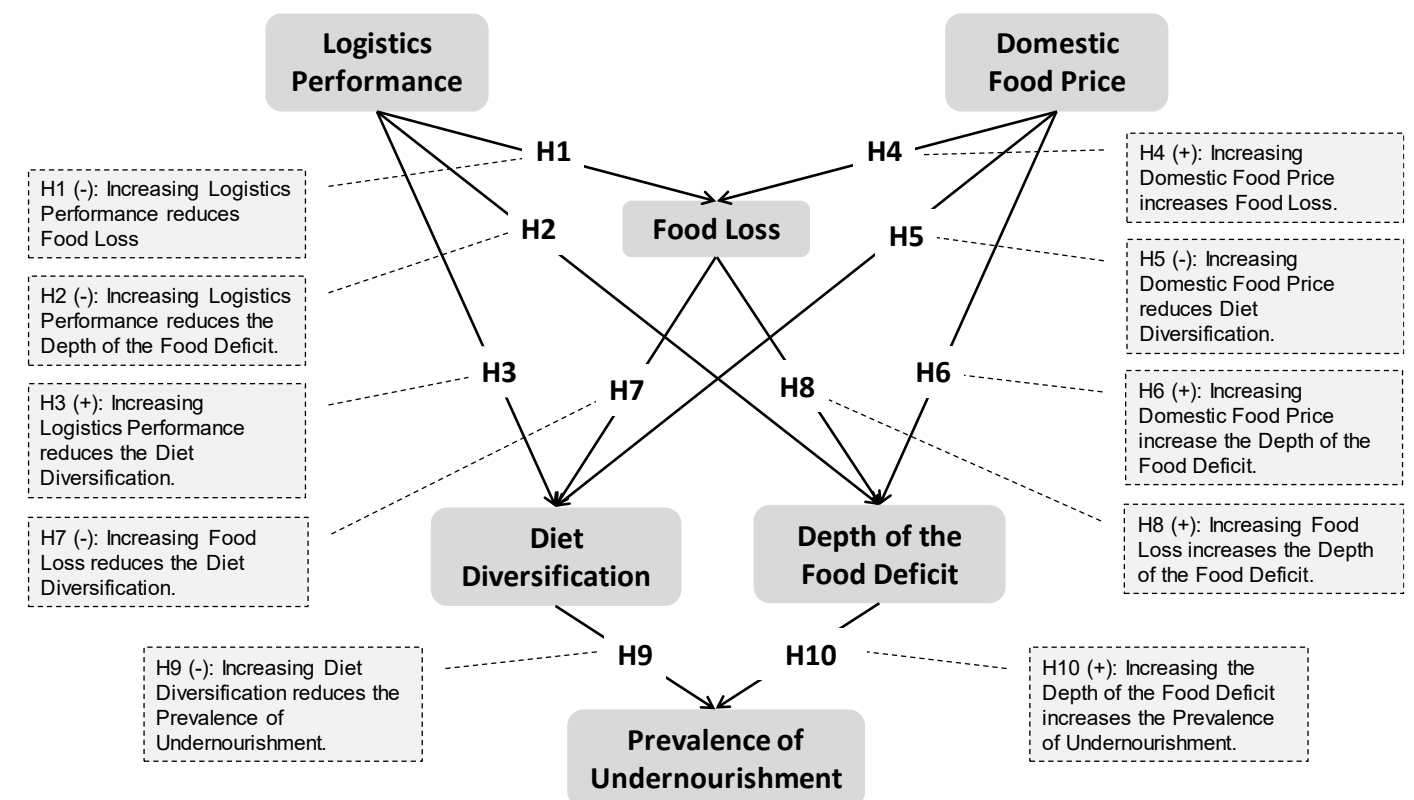

Figure 1 - Reference Model and Hypotheses

Source: The authors

This study aimed to corroborate the assumptions that logistics performance tends to reduce food loss (hypothesis 1), reduce depth of food deficit (hypothesis 2), and improve diet diversification (hypothesis 3) for the world's populations. Earlier evidence showed that a considerable share of food losses is caused by an inefficient logistical process, mostly for food with a reduced shelf life (Jedermann et al., 2014; Liljestrand, 2017) and logistic improvement is a 
priority in order to reduce food waste worldwide (Thyberg \& Tonjes, 2016). Also, logistical inefficiency, considering the infrastructure, the articulation between the economic agents and their management capacity, is among the main reasons that cause food waste worldwide, aggravating the situation of food insecurity (Parfitt et al., 2010). As depth of food deficit indicates how many calories would be needed to lift the undernourished from their status, everything else being constant (FAO, 2018b), it seems reasonable to assume that better logistics performance can improve the main conditions in order to properly supply nations with an adequate amount of food capable to supply their needs. Moreover, since foods locally produced are supplied globally, it is logical to assume that logistics has an important role in the supply challenge, mostly for those foods with reduced shelf life.

The study also aimed to present evidence in order to sustain that domestic food prices, evaluated through the domestic food price index (Capone et al., 2014), tend to increase food loss (hypothesis 4), reduce diet diversification (hypothesis 5) and increase depth of food deficit (hypothesis 6) for the world's populations. Higher prices harm the buying power of a given population, affecting the proper food supply and consumption. Furthermore, if the price of a given crop is too low, harming the economic gain for farmers and their conditions to pay for logistics, processing, and selling costs, it may be more reasonable for the producer to give it away (Lipinski et al., 2013). Also, reducing the food loss has the potential to reduce food supply costs, hence reducing the food price for the final consumer (Papargyropoulou et al., 2014), promoting better food security conditions.

In addition, reducing food loss tends to increase diet diversification (hypothesis 7) and reduce depth of food deficit (hypothesis 8). Earlier evidence showed that fruit and vegetables are the food groups with higher loss levels (Sagar et al., 2018), possibly harming the diet diversification of some populations in developing nations. Indeed, loss of fruit and vegetables during the production and distribution stages is estimated to reach about $50 \%$ to $60 \%$ in developing countries (Gustavsson et al., 2011; Sagar et al., 2018). Furthermore, proper access conditions might not be achieved in poor regions worldwide since a great amount of food is lost before it reaches the final consumer. Finally, this study states that higher level of diet diversification is associated with lower prevalence of undernourishment (hypothesis 9), as well as higher level of depth of food deficit is associated with higher prevalence of undernourishment (hypothesis 10) in nations worldwide.

This research study is based on available data obtained via official agencies such as the Food and Agriculture Organization (FAO) (FAO, 2019, 2020), Global Food Security Index (Gfsi) (Gfsi, 2019), and the World Bank Group (World Bank, 2019). Table 1 presents the main variables analyzed in this study, as well as their descriptions and official sources.

The reference model and main hypotheses presented in figure 1 were investigated through correlation and multiple regression analyses. In order to properly test the main hypotheses, the study evaluated four equations separately through multiple linear regression analyses. Since the database contains multiple missing values, modeling of structural equations is not suggested for this investigation. This investigation adopted Pearson's correlation analysis in order to describe the association level between the main variables, and multiple regression analysis in order to perform the hypotheses testing. Thus, this study used scatter plots to present the findings considering the main variables addressed. Scatter plots allow the visualization of the position for each country considering their situation regarding food price, food loss, logistics performance, diet diversification, and undernourishment. These scatter plots also show regression results using nonlinear equations. 
Table 1 - Main variables, descriptions and sources

\begin{tabular}{|c|c|c|}
\hline Variable & Description & $\begin{array}{c}\text { Source and } \\
\text { Period }\end{array}$ \\
\hline $\begin{array}{l}\text { Logistics } \\
\text { Performance Index } \\
\text { (LPI) }\end{array}$ & $\begin{array}{l}\text { The LPI is the weighted average of the country scores on the six key dimensions, } \\
\text { published by the World Bank Group (World Bank, 2019). }\end{array}$ & $\begin{array}{l}\text { World Bank } \\
\quad(2019)\end{array}$ \\
\hline $\begin{array}{l}\text { Domestic Food } \\
\text { Price Index (DFPI) }\end{array}$ & $\begin{array}{l}\text { The DFPI is given by the ratio between the Food Purchasing Power Parity (Fppp) } \\
\text { and the General PPP, resulting in an index of the price of food in the country } \\
\text { relative to the price of the generic consumption basket (Capone et al., 2014; FAO, } \\
2001,2018 \mathrm{a} \text { ) }\end{array}$ & $\begin{array}{l}\text { FAO (2011- } \\
\text { 2014) }\end{array}$ \\
\hline Food Loss & $\begin{array}{l}\text { This variable is a measure that considers post-harvest and pre-consumer food loss } \\
\text { as a ratio of the domestic agricultural supply (Gfsi, 2019). }\end{array}$ & GFSI (2019) \\
\hline Diet Diversification & $\begin{array}{l}\text { A measure of the share of non-starchy foods in total dietary energy consumption. } \\
\text { Greater is the share of non-starchy foods, greater is the diversity of food groups in } \\
\text { the diet (Gfsi, 2019). }\end{array}$ & $\begin{array}{l}\text { GFSI (2011- } \\
\text { 2013) }\end{array}$ \\
\hline $\begin{array}{l}\text { Depth of the food } \\
\text { deficit (kilocalories } \\
\text { per person per day) }\end{array}$ & $\begin{array}{l}\text { The depth of the food deficit indicates how many calories would be needed to lift } \\
\text { the undernourished from their status, everything else being constant (FAO, 2018a) }\end{array}$ & $\begin{array}{l}\text { FAO (2011- } \\
\text { 2013) }\end{array}$ \\
\hline $\begin{array}{l}\text { Prevalence of } \\
\text { Undernourishment } \\
(\%)\end{array}$ & $\begin{array}{l}\text { The prevalence of undernourishment (PoU) represents the proportion of the } \\
\text { population whose habitual food consumption is not enough to provide the amount } \\
\text { of dietary energy required to maintain a normal active and healthy life (FAO, } \\
\text { 2019) }\end{array}$ & FAO (2014) \\
\hline
\end{tabular}

Source: The authors

The sample of countries (n) considered in the multivariate statistical analyses (correlations and regressions) reported in the results section was the number of countries with available official data. To evaluate the statistical accuracy for regression equations, the study used the adjusted $\mathrm{R}^{2}$ (coefficient of determination) values and $\mathrm{p}$-values. $\mathrm{R}^{2}$ indicates the percentage of the total variance of the dependent variable that is explained by the regression model (Hair et al., 1995; Tabachnick et al., 2007).

\section{RESULTS}

This section presents the main results obtained for this investigation. Table 2 presents the correlational map, considering the six main variables addressed in the study, showing Pearson's correlation coefficient, the number of valid observations analyzed in pairwise (n), and the statistical significance value (p-value). Table 3 presents the main results obtained for hypotheses testing, showing the regression coefficients with their respective $p$-values, as well as the $\mathrm{R}^{2}$ for the regression equations.

Table 2 - Correlation Map

\begin{tabular}{|c|c|c|c|c|c|}
\hline & $\begin{array}{c}\text { Logistics } \\
\text { Performance Index } \\
\text { (LPI) } \\
\end{array}$ & $\begin{array}{l}\text { Domestic } \\
\text { Food Price } \\
\text { Index } \\
\end{array}$ & Food Loss & $\begin{array}{c}\text { Diet } \\
\text { Diversification }\end{array}$ & $\begin{array}{l}\text { Depth of the } \\
\text { food deficit }\end{array}$ \\
\hline $\begin{array}{l}\text { Domestic Food } \\
\text { Price Index }\end{array}$ & $\begin{array}{c}-0.7740 * * * \\
\mathrm{n}=122\end{array}$ & 1 & - & - & - \\
\hline Food Loss & $\begin{array}{c}-0.5006^{* * *} \\
\mathrm{n}=103\end{array}$ & $\begin{array}{c}+0.4696^{* * *} \\
\mathrm{n}=102\end{array}$ & 1 & - & - \\
\hline $\begin{array}{l}\text { Diet } \\
\text { Diversification } \\
\end{array}$ & $\begin{array}{c}+0.6977 * * * \\
\mathrm{n}=103\end{array}$ & $\begin{array}{c}-0.8288 * * * \\
\mathrm{n}=102\end{array}$ & $\begin{array}{c}-0.4441 * * * \\
\mathrm{n}=113\end{array}$ & 1 & - \\
\hline $\begin{array}{l}\text { Depth of the food } \\
\text { deficit }\end{array}$ & $\begin{array}{c}-0.2907 * * \\
\mathrm{n}=100 \\
\end{array}$ & $\begin{array}{c}+0.4869^{* * *} \\
\mathrm{n}=88\end{array}$ & $\begin{array}{c}+0.0724 \\
\mathrm{n}=75\end{array}$ & $\begin{array}{c}-0.3618^{* *} \\
\mathrm{n}=75\end{array}$ & 1 \\
\hline $\begin{array}{l}\text { Prevalence of } \\
\text { Undernourishment }\end{array}$ & $\begin{array}{c}-0.5152 * * * \\
\mathrm{n}=143\end{array}$ & $\begin{array}{c}+0.6342 * * * \\
\mathrm{n}=133\end{array}$ & $\begin{array}{c}+0.3148^{* *} \\
\mathrm{n}=106\end{array}$ & $\begin{array}{c}-0.5891 * * * \\
\mathrm{n}=106\end{array}$ & $\begin{array}{c}+0.9099 * * * \\
\mathrm{n}=114\end{array}$ \\
\hline
\end{tabular}

Note: $* * * \mathrm{p}<0.0001 ; * * \mathrm{p}<0.001$.

Source: The authors

The results showed that logistic performance has a negative and significant correlation with domestic food price $(\rho=-0.7744 ; p<0.0001)$, food loss level $(\rho=-0.5006 ; p<0.0001)$, depth of 
Food price, losses and logistics affecting diet diversification and food security

food deficit $(\rho=-0.2907 ; p=0.003)$, and prevalence of undernourishment $(\rho=-0.5152 ; p<0.0001)$, suggesting that countries with better logistic performance tend to have lower food loss level, lower prices in domestically supplied food, lower depth of food deficit, and lower severity in the prevalence of population's undernourishment. On the other hand, logistics performance has a positive and significant correlation with diet diversification $(\rho=+0.6977 ; p<0.0001)$, suggesting that countries with more improved logistics tend to provide better dietary diversity to their populations.

Evidence also showed that the domestic food price has a positive and significant correlation with food loss $(\rho=+0.4696 ; p<0.0001)$, depth of food deficit $(\rho=+0.4869 ; p<0.0001)$, and prevalence of undernourishment $(\rho=+0.6342 ; p<0.0001)$. In addition, domestic food price has a negative and significant correlation with diet diversification $(\rho=-0.8288 ; p<0.0001)$. These results suggest that countries with higher prices for domestically offered food also tend to have higher levels of food waste, lower levels of dietary diversification, and higher levels of undernourishment and food insecurity.

The evidence from the study also demonstrated that food loss has a positive and significant correlation with prevalence of undernourishment $(\rho=+0.3148 ; p=0.001)$. In contrast, food loss has a negative and significant correlation with diet diversification $(\rho=-0.4441 ; p<0.0001)$, suggesting that loss of food implies a possible reduction in dietary diversity, and significantly affects the conditions of nations in promoting food security for their people.

The findings display that depth of food deficit and prevalence of undernourishment present a strong positive correlation $(\rho=+0.9099 ; \mathrm{p}<0.0001)$. The study also revealed that diet diversification has a negative and significant correlation with depth of food deficit $(\rho=-0.3618 ; p=$ $0.001)$ and prevalence of undernourishment $(\rho=-0.5891 ; p<0.0001)$, suggesting that dietary diversification has the potential to help reduce malnutrition and promote food security.

Table 3 - Results for hypotheses testing

\begin{tabular}{|c|c|c|c|c|c|c|c|}
\hline & $\begin{array}{c}\text { Dependent } \\
\text { Variables }\end{array}$ & Independent Variables & $\boldsymbol{\beta}$ & p-value & $\begin{array}{c}\text { Hypothesis } \\
\text { testing }\end{array}$ & $\mathbf{R}^{2}$ & $\mathbf{N}$ \\
\hline \multirow{3}{*}{ تே } & \multirow{3}{*}{ Food Loss } & Intercept & 11.3597 & 0.0084 & - & \multirow{3}{*}{0.3043} & \multirow{3}{*}{94} \\
\hline & & Logistics Performance & -2.4923 & 0.0252 & H1: accepted & & \\
\hline & & Domestic Food Price & 0.3307 & 0.1374 & H4: rejected & & \\
\hline \multirow{4}{*}{$\stackrel{\sim}{\dot{I}}$} & \multirow{4}{*}{ Diet Diversification } & Intercept & 66.9780 & 0.0000 & - & \multirow{4}{*}{0.7250} & \multirow{4}{*}{94} \\
\hline & & Logistics Performance & 2.2902 & 0.4119 & H3: rejected & & \\
\hline & & Domestic Food Price & -4.0915 & 0.0000 & H5: accepted & & \\
\hline & & Food Loss & -0.3910 & 0.1343 & H7: rejected & & \\
\hline \multirow{4}{*}{ m } & \multirow{4}{*}{ Depth of Food Deficit } & Intercept & 216.8745 & 0.0936 & - & \multirow{4}{*}{0.4484} & \multirow{4}{*}{63} \\
\hline & & Logistics Performance & -68.0954 & 0.0688 & H2: rejected & & \\
\hline & & Domestic Food Price & 21.6846 & 0.0002 & H6: accepted & & \\
\hline & & Food Loss & -6.7720 & 0.0127 & H8: rejected & & \\
\hline \multirow{3}{*}{$\dot{+}$} & \multirow{3}{*}{$\begin{array}{l}\text { Prevalence of } \\
\text { Undernourishment }\end{array}$} & Intercept & 6.6855 & 0.0062 & - & \multirow{3}{*}{0.8490} & \multirow{3}{*}{74} \\
\hline & & Diet Diversification & -0.0729 & 0.1020 & H9: rejected & & \\
\hline & & Depth of Food Deficit & 0.1023 & 0.0000 & H10: accepted & & \\
\hline
\end{tabular}

Source: The authors

The results obtained for equation 1 showed evidence that corroborated hypothesis $\mathrm{H} 1(\beta=-$ $2.4923 ; p=0.0252$ ), suggesting that logistics performance negatively impacts the levels of food loss of the world's nations. On the other hand, hypothesis H4 was refuted $(\beta=0.3307 ; p=0.1374)$ since the results show that domestic food price does not significantly affect the levels of food loss of the world's nations considered in this study.

Equation 2 corroborates the hypothesis H5 of this study $(\beta=-4.0915 ; \mathrm{p}=0.0000)$, suggesting that domestic food price has a significant impact on diet diversification, evidencing that a reduction in food prices has the potential to promote greater diet diversification for populations worldwide. In contrast, hypotheses H3 and H7 were refuted $(\beta=2.2902 ; p=0.4119$, and $\beta=$ - 
$0.3910 ; \mathrm{p}=0.1343$, respectively), suggesting that logistics performance and food loss do not significantly impact the diet diversification of the world's populations.

Hypotheses H2, H6 and H8 were tested using the multiple linear regression estimated in equation 3. The results of the study corroborated hypothesis H6 $(\beta=21.6846 ; p=0.0002)$, suggesting domestic food price implies a significant increase in depth of food deficit in the world populations. On the other hand, hypotheses $\mathrm{H} 2$ and $\mathrm{H} 8$ have been refuted $(\beta=-68.0954 ; \mathrm{p}=0.0688$, and $\beta=-6.7720 ; p=0.0127$, respectively), suggesting that logistics performance and food loss do not imply an increase in depth of food deficit worldwide. The result obtained for hypothesis $\mathrm{H} 8$ has statistical significance, but the negative coefficient obtained for the predictive variable implies a rejection of the working hypothesis. This result raises questions about the relationship between food waste and the prevalence of food insecurity within the unit of analysis. It is logical to assume that high levels of FLW tend to increase the severity of food insecurity worldwide; however, it does not mean that countries with higher levels of food loss are the same countries with the highest levels of depth of food deficit and food insecurity.

Equation 4 presents the results for hypotheses H9 and H10. The results of the study corroborated hypothesis H10 $(\beta=0.1023 ; p=0.0000)$, suggesting that depth of food deficit implies a significant increase in the prevalence of undernourishment in the world's populations. On the other hand, hypothesis $\mathrm{H} 9$ has been refuted $(\beta=-0.0729 ; \mathrm{p}=0.1020)$, suggesting that diet diversification does not significantly affect the prevalence of undernourishment of the world's populations. 


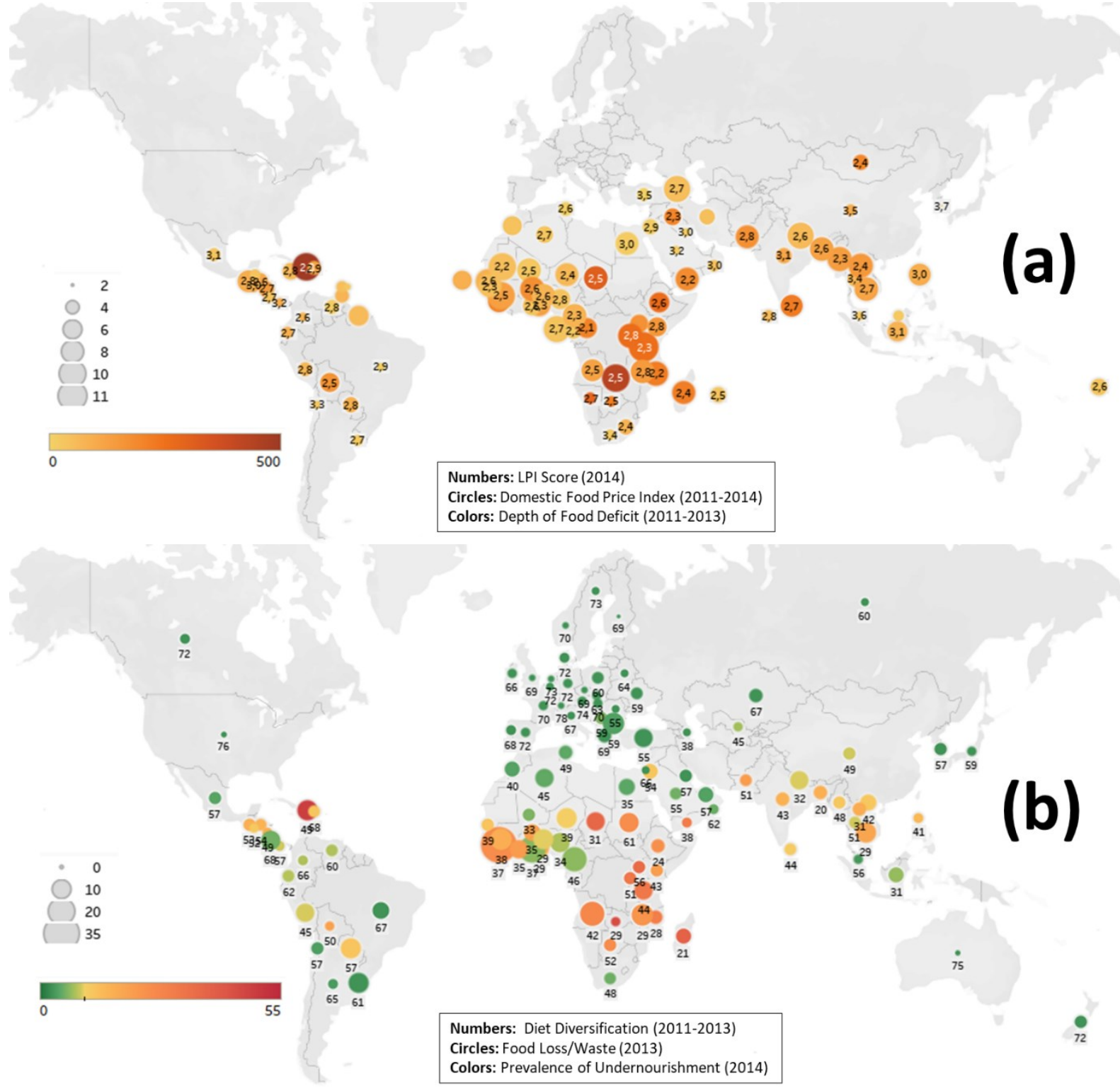

Figure 2 - World visualization for the main variables of the study Source: The authors

This study presents figure 2 in order to visualize countries' profiles regarding the main variables addressed in the investigation. Figure $2 \mathrm{a}$ shows the depth of food deficit (in $\mathrm{kcal} / \mathrm{person} /$ day) at the color scale, the domestic food price index at the circle scale, and the logistics performance index (LPI) at numeric labels. Figure $2 b$ shows the prevalence of undernourishment (\%) at the color scale, food loss at the circle scale, and diet diversification at numeric labels.

It is possible to observe that some countries located in Eastern Africa, Western Africa, South Asia, and Latin America (especially Haiti) have high levels of depth of food deficit, lower levels of logistics performance and high levels of domestic food price. Thus, some of these present high levels of food loss, lower diet diversification and higher prevalence of undernourishment. Special attention should be given to Haiti, Sierra Leone, Eastern Africa, and Central Africa. Also, lack of logistics performance surrounding vulnerable countries with high prevalence of undernourishment seems to compromise their adequate access to food security conditions.

The next four figures show scatter plots confronting the main variables addressed in this investigation. Figure 3 shows a scatter plot considering diet diversification at the $\mathrm{Y}$-axis, and 
domestic food price index at the X-axis. Also, the visualization allows to observe the LPI score and the prevalence of undernourishment for countries.

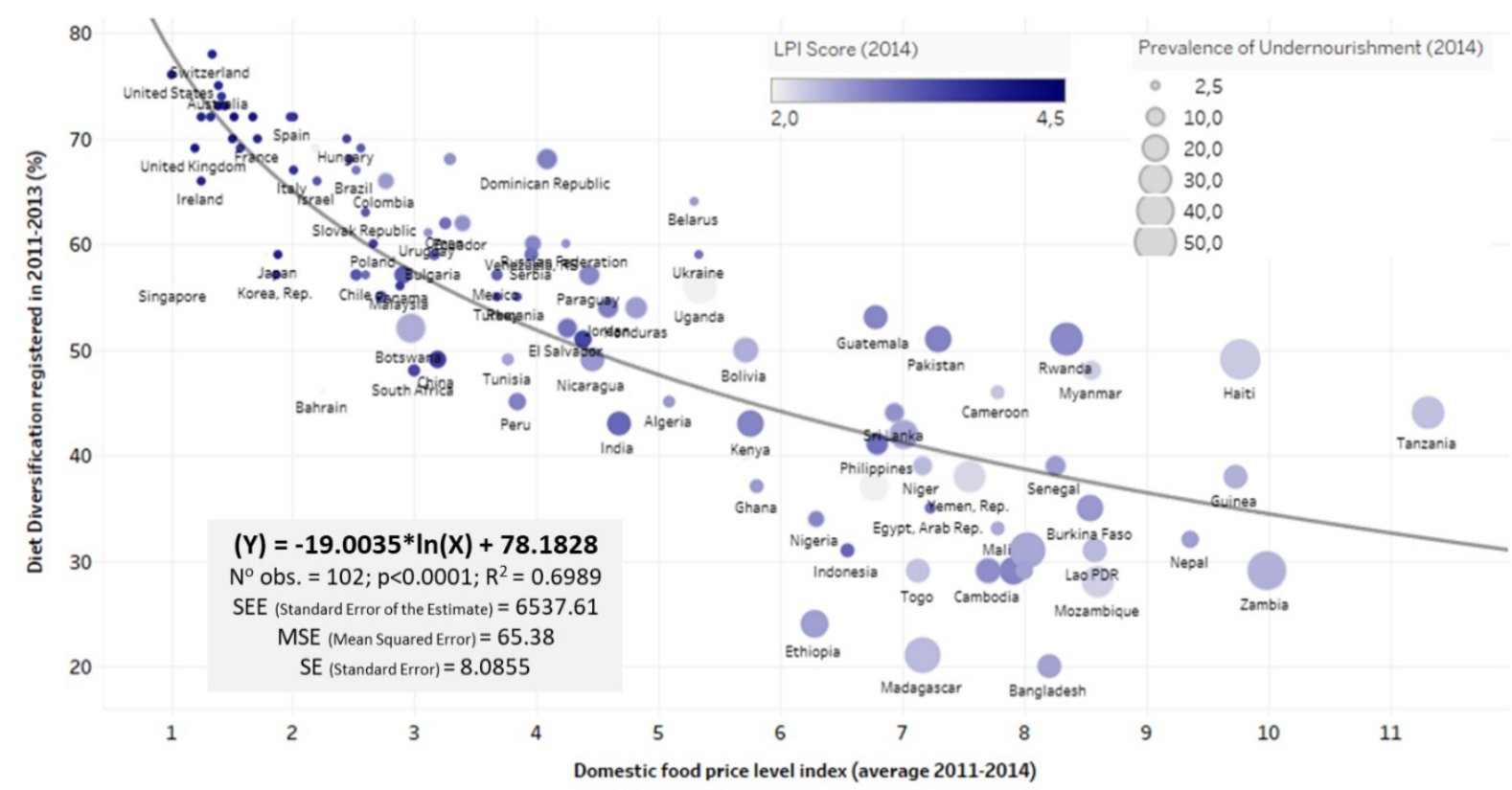

Figure 3 - Scatter plot comparing Diet Diversification (Y-axis), Domestic Food Price Index (X-axis), LPI Score (color scale) and Prevalence of Undernourishment (circle scale)

Source: The authors

Figure 3 shows there is a strong association between domestic food price and diet diversification, presenting a non-linear equation (logarithmic model) highly significant $\left(\mathrm{R}^{2}=\right.$ $0.6989 ; \mathrm{p}<0.0001)$. This result suggests that an increase in food price tends to decrease diet diversification on populations worldwide, being logical to assume that some food groups tend to be less consumed as their prices become more expensive. Also, Figure 3 shows that countries with higher prevalence of undernourishment (larger circles) and lower logistics performance (lighter blue) present higher domestic food price and lower diet diversification.

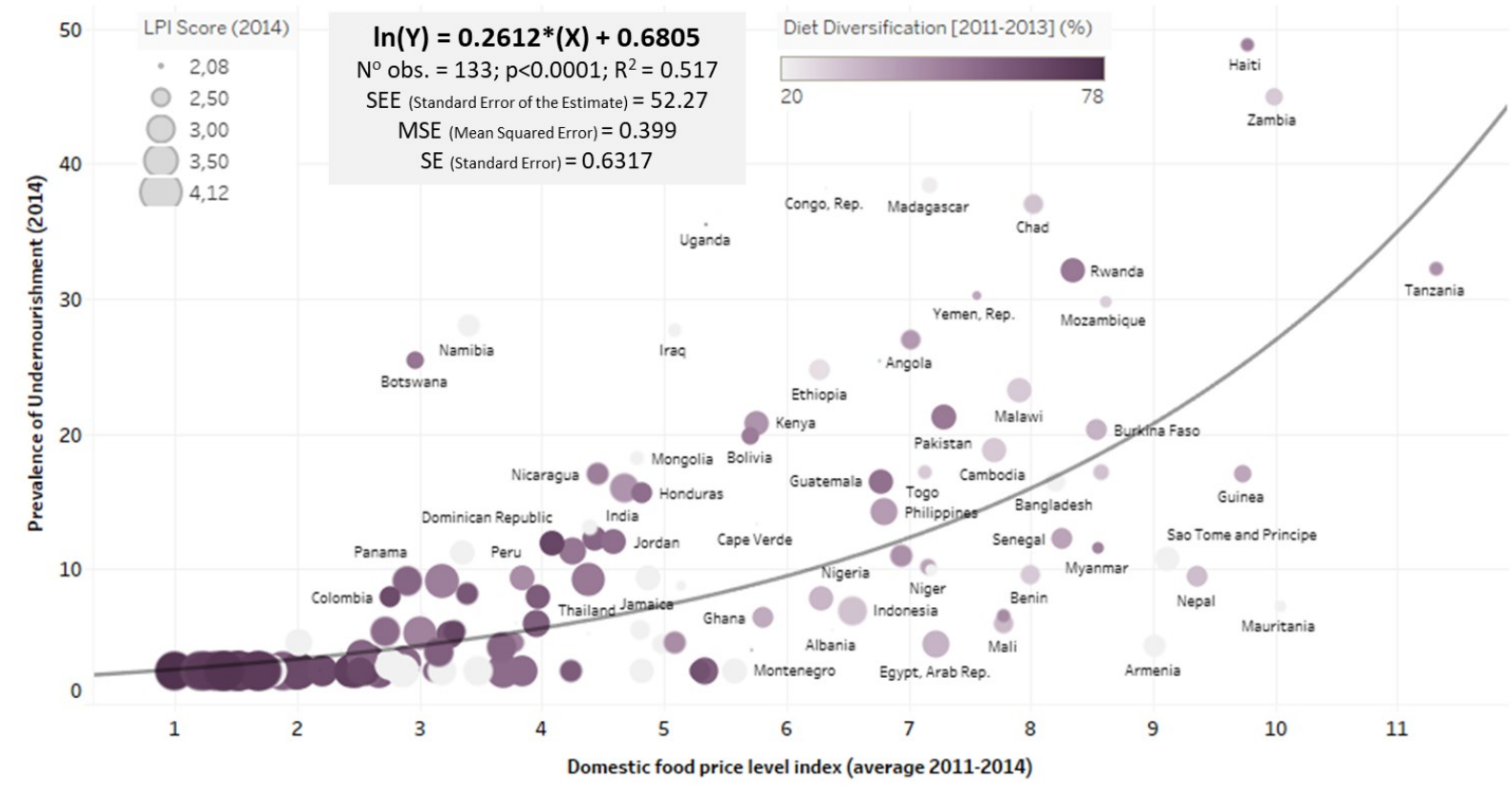

Figure 4 - Scatter plot comparing Prevalence of Undernourishment (Y-axis), Domestic Food Price Index (X-axis), LPI Score (circle scale) and Diet Diversification (color scale) Source: The authors 
Food price, losses and logistics affecting diet diversification and food security

Figure 4 presents a scatter plot highlighting the prevalence of undernourishment (\%) at the $\mathrm{Y}$-axis, and domestic food price index at the X-axis, adding the LPI score and diet diversification as second visualized dimensions. Figure 4 reveals the existence of a moderate relationship between domestic food price and prevalence of undernourishment, presenting a non-linear equation (exponential model) statistically significant $\left(\mathrm{R}^{2}=0.517 ; \mathrm{p}<0.0001\right)$. This evidence suggests that increasing the food price tends to result in an increase in prevalence of undernourishment in nations worldwide, reinforcing that price is a key factor in order to promote a proper food supply globally, helping to ensure food security for world populations. Moreover, Figure 4 shows that countries with better logistics performance (larger circles) and higher diet diversification (darker purple) tend to present lower domestic food price and lower prevalence of undernourishment.

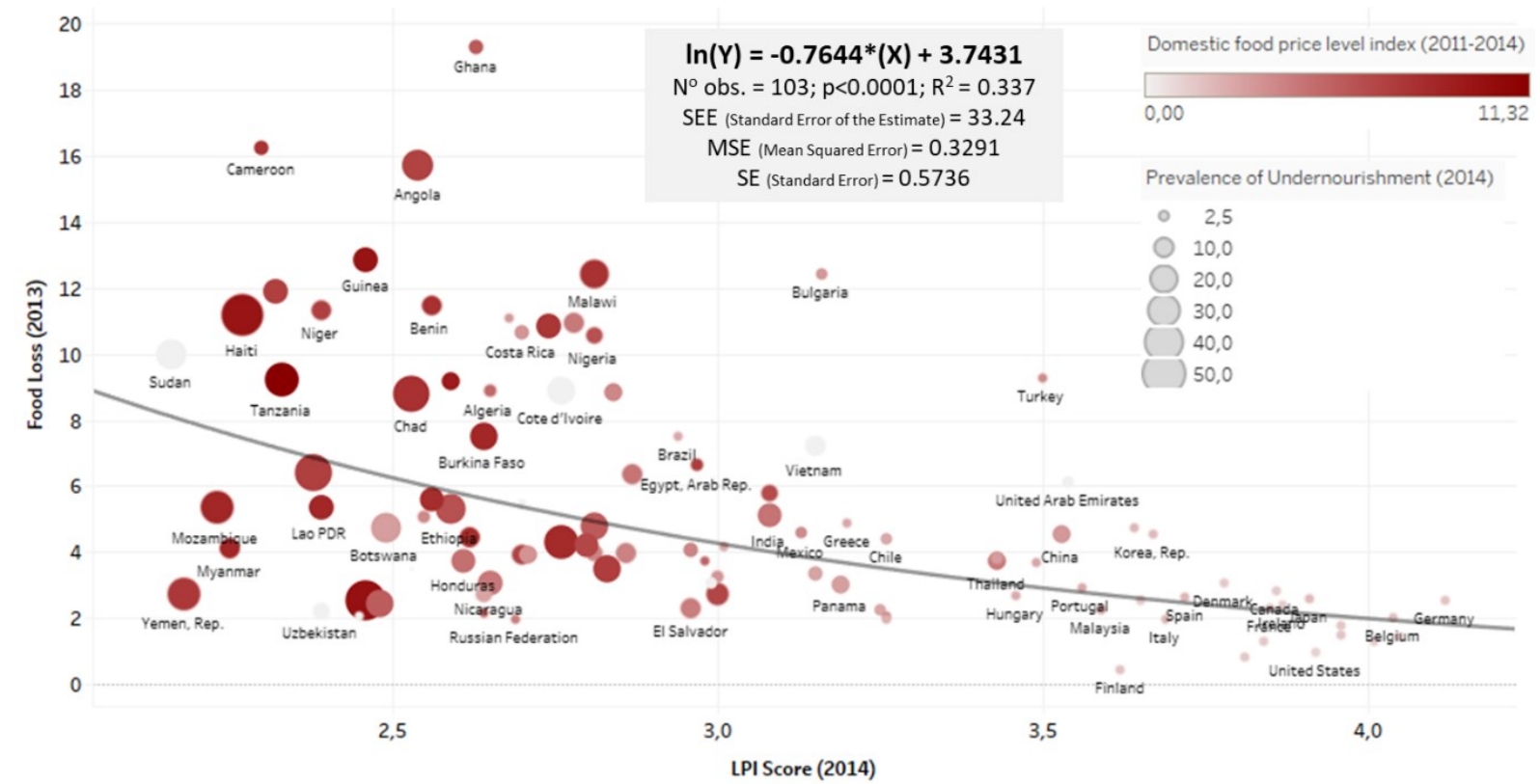

Figure 5 - Scatter plot comparing Food Loss (Y-axis), LPI Score (X-axis), Domestic Food Price Index (color scale) and Prevalence of Undernourishment (circle scale)

Source: The authors

Figure 5 presents a scatter plot showing food loss at the Y-axis, and LPI score at the X-axis. Also, the visualization shows the domestic food price index and prevalence of undernourishment. Figure 5 suggests the existence of a moderate relationship between LPI score and food loss, presenting a non-linear equation (exponential model) with lower accuracy, but still statistically significant $\left(\mathrm{R}^{2}=0.337 ; \mathrm{p}<0.0001\right)$. This evidence suggests that increasing the logistics performance tends to decrease food loss in nations worldwide. In addition, countries with higher prevalence of undernourishment (larger circles) and higher domestic food price (darker red) tend to present lower logistics performance. On the other hand, higher level of food loss is observed in many nations, hardly being directly associated with the prevalence of undernourishment. This highlights the complexity of the relationship between food loss and food security worldwide. 


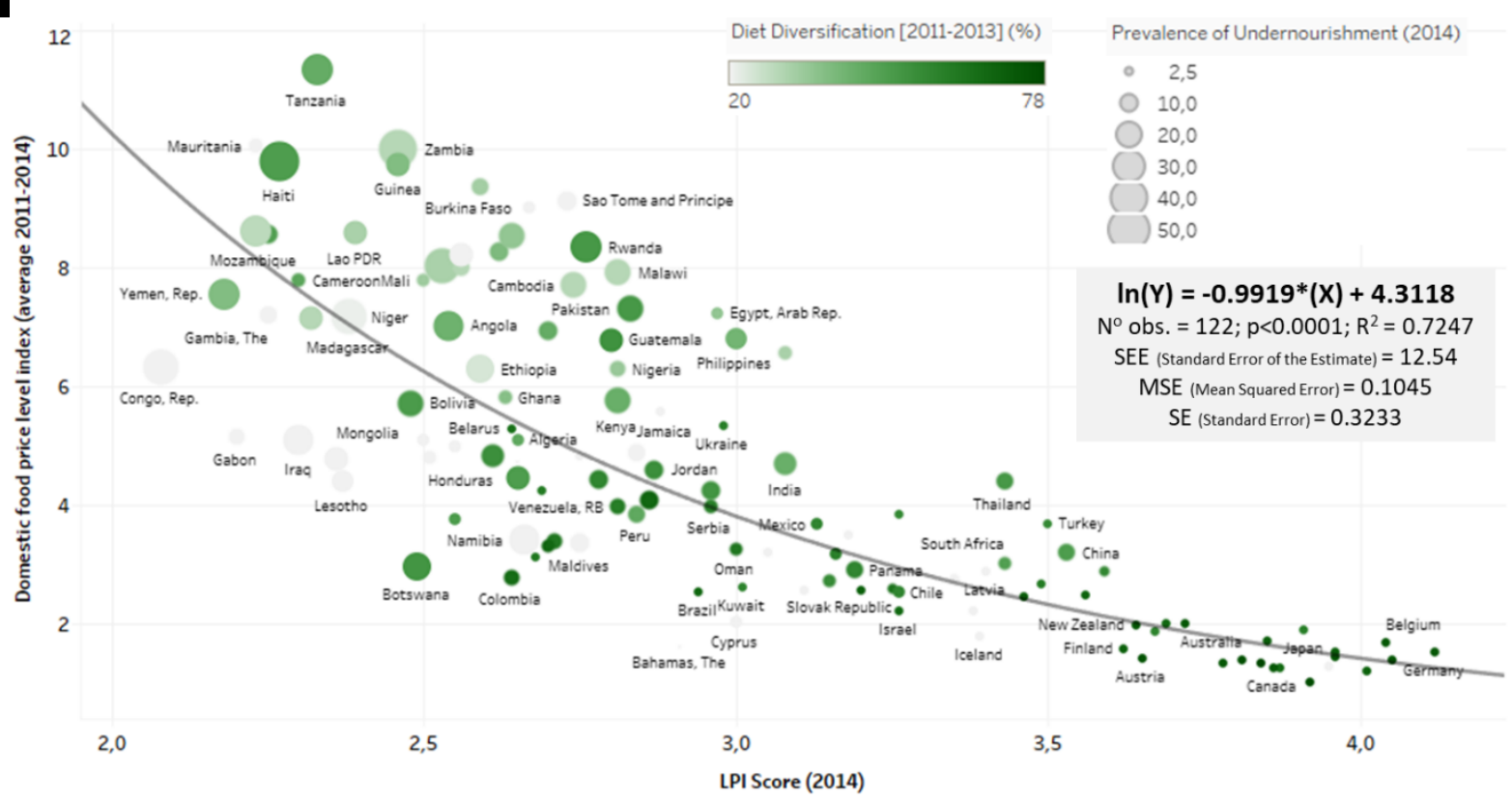

Figure 6 - Scatter plot comparing Domestic Food Price Index (Y-axis), LPI Score (X-axis), Diet Diversification (color scale) and Prevalence of Undernourishment (circle scale)

Source: The authors

Lastly, Figure 6 presents a scatter plot highlighting the domestic food price index at the Yaxis and LPI score at the X-axis, adding the prevalence of undernourishment and diet diversification as second visualized dimensions. Figure 6 shows the existence of a strong association between logistics performance and domestic food price, presenting a non-linear equation (exponential model) highly significant $\left(\mathrm{R}^{2}=0.7247 ; \mathrm{p}<0.0001\right)$. This result suggests that an increase in logistics performance tends to be associated with a decrease in domestic food prices in nations worldwide. In addition, Figure 6 shows a prevalence of countries with lower logistics performance and higher levels of undernourishment (larger circles), as well as higher logistics performance and better diet diversification (darker green).

\section{DISCUSSION}

The world faces a great challenge in order to promote food security to its increasing population. FLW can be faced as an indirect significant antecedent for food insecurity, affecting diet diversity and nutrients' availability for the world's population. The findings presented here sustain that logistics performance impacts on food loss, and such waste represents a waste of nutritional potential that could be used to promote food security worldwide, despite higher levels of food loss not being registered in those countries with higher levels of food insecurity.

Even in developed countries, levels of food waste are high. In the United States, $41 \%$ of perishable foods (meat, poultry, and fish) are wasted in the retail and consumer stages (Buzby \& Hyman, 2012). In Europe, about 280-300 kg of food per capita per year is wasted along the entire food supply chain, and such waste occurs in several stages of the production, distribution and consumption processes (FAO, 2011; Gustafsson et al., 2013). Also, FLW represents a waste of natural and economic resources, including water, fuel, land, fertilizer, pesticides and other agricultural chemicals (Johnson et al., 2018; Kummu et al., 2012).

It is observed that global food distribution is not in line with global food demands (De Schutter, 2010), and the discussion regarding FLW is highly relevant to promote and assure food security worldwide. The FLW observed on a global scale is possibly aggravated by the logistical weaknesses faced by nations, as well as by high levels of food prices in some international markets. In fact, previous studies argue that the logistics infrastructure offers conditions to promote better 
Food price, losses and logistics affecting diet diversification and food security

physical access to food, while more affordable prices promote conditions to promote better economic access to food (Babu et al., 2014; Butcher et al., 2018).

It is also important to consider that commercial food transactions between the nations of the world can increase the degree of food loss, as displacement and long periods of storage and transport, as well as waiting times at customs, can damage food more fragile and with reduced shelf life (Bacenetti et al., 2018), such as fruits and vegetables, making them unsuitable for human consumption. Therefore, promoting the consumption of locally produced food may represent a strategy to reduce food waste, while promoting local economic development. Also, food processing enabling and ensuring nutrient content, safety and shelf life of foods, can be a valid strategy (Augustin et al., 2016).

Concerning food prices, FLW that occurs in a particular locality/country is likely to lead to price increases in other localities/countries, which explains why food loss does not have a significant direct impact on food insecurity in countries but it does affect world price dynamics, indirectly aggravating food insecurity globally. Regarding this, the concept of food poverty has critical importance since it enhanced by the reduction in consumer purchasing power possibly caused by food price volatility (O'Connor et al., 2016).

Price is a variable that has the potential to aggravate food loss in several ways. At the beginning of a food supply chain, lower prices can harm the economic gain of farmers, resulting in higher levels of food loss (Lipinski et al., 2013), as well as higher prices might affect the strategic position related to costs of buyers and processing industries that can possibly search for cheaper offers in other markets, leading to a food loss in markets with expensive prices. Also, at the end of the supply chain, lower prices or higher volatility in price can lead to exaggerated purchases in households, generating food waste (Porpino et al., 2015). On the other hand, high prices can cause consumers to look for alternative products offered at lower prices (substitute products), which can generate waste for retailers and food service companies. Thus, since reducing FLW has the potential to reduce the food price for final consumers (Papargyropoulou et al., 2014), pricing being considered as a mechanism of market regulation, together with the level of food waste, sets up an equation with a recursive behavior.

Food loss and diet diversification are burdens that affect the adequate promotion of food security. This investigation has focused its attention on elucidating these variables under an economic bias. However, food loss and diet diversification, as dimensions of food security, can be improved through educational initiatives (Aschemann-Witzel et al., 2017; Sandell et al., 2016), since these concepts are strongly related to behavioral traits of individuals and populations.

\subsection{Theoretical and practical implications}

Some African nations present high levels of food loss and undernourishment, mostly in regions with higher deficits in logistics performance and higher food prices, highlighting that logistics investments and policies regarding food pricing are necessary to promote food security in some developing nations. It is also possible to observe that some countries with reduced levels of undernourishment and high levels of food loss border other countries that have a more fragile situation in terms of undernourishment. A better understanding about the main causes of FLW in specific countries can help policymakers to promote sustainable development and food security worldwide through adequate access, supply, and local development.

The supply and consumption of locally produced food represent a strategy with the potential to promote better food and nutritional supply and consumption for economically and socially vulnerable populations. In this scenario, enhancing urban agriculture has the potential to help promote food security for poorer populations, strengthening the local economy and furthering greater dietary diversity (Dimitri et al., 2016; Poulsen et al., 2015; Zezza \& Tasciotti, 2010). In addition, strengthening the consumption of locally produced foods through the promotion of short food supply chains, regional development, and urban agriculture has the potential to reduce FLW 
levels, especially for food groups with a shorter shelf life (Spada et al., 2018). Moreover, such local development has the potential to reduce environmental impacts such as GHG emissions and waste of natural resources employed in the production of wasted food (Nogeire-McRae et al., 2018; Sanyé-Mengual et al., 2018).

It is important to highlight that these strategies concentrated on the consumption of locally produced food, urban agriculture, and regional development need to be supported by initiatives focused on the behavior of producers and consumers, as well as definitions of market regulatory mechanisms that foster new patterns of food production and consumption. These initiatives have the potential to ensure the development of more efficient, competitive, safe and sustainable food systems. Hence, efforts in order to delineate and disseminate sustainable and healthier diets are required to assist in reducing FLW as well as environmental impacts and health expenditures (Abbade, 2018; Macdiarmid et al., 2016; Mason et al., 2017).

The evidence presented here can assists policymakers so that specific policies and actions are taken to encourage more appropriate pricing policies in order to help promote global food security. Therefore, strategic actions in the private sector are strongly needed since the proper management of food supply chains and better designed food systems might help significantly with the proper definition of price policies, thus helping to reduce FLW levels.

\subsection{Limitations of the study}

The equations resulting from the regression models developed in this study are not sufficiently universal to predict undernourishment, food loss, or the other endogenous concepts addressed in the reference model. The findings highlight the complexity of the concepts addressed here, suggesting that more data and additional investigation should be considered in order to promote a better understanding of the burdens of food security and malnutrition worldwide.

\subsection{Suggestions for future studies}

Future studies should focus on the issue of proper world food supply and the promotion of food security for the most vulnerable populations. It is also necessary to conduct economic studies that aim to present pertinent evidence with the potential to promote the reduction of the misuse of natural resources that end up being wasted, affecting food prices and increasing environmental impacts. Moreover, additional investigations should analyze specific food groups or specific regions of the world in order to promote a better understanding of the issues addressed here. Efforts to build and consolidate improved global food systems, particularly considering staple foods, should be priorities for governments and the private sector in order to reduce food prices, promoting cleaner food production, mitigating environmental damages, and promoting sustainable food security.

Studies using the LCA (Life Cycle Assessment) approach are strongly encouraged to elucidate the main causes and consequences of FLW as well as its impacts on the environment, helping to promote food security worldwide. Indeed, earlier studies that focused on the investigation of FLW and its environmental impacts using the LCA approach presented important findings (Gutierrez et al., 2017; Jin et al., 2015; Schott \& Andersson, 2015). However, earlier studies also highlight the discrepancy of FLW definition and the application of LCA approach for this purpose (Corrado et al., 2017). There are several opportunities for additional research regarding FLW using the LCA approach in order to evaluate the use of natural resources for food production and the resulting FLW, as well as the assessment of energy and nutritional potential associated with the amount of FLW. Also, considering specific stages in the food supply chain, additional elements, such as packing, industrial processing, and retail resources, might be incorporated into the analytical procedures regarding the LCA approach.

Considering the thematic issue in question, it is suggested that additional empirical studies related to the theme be conducted, aiming to identify the main causes of food waste in the various 
stages of the production, distribution and consumption process. With this, through objective evidence obtained in scientific investigations, it will be possible to scientifically base decisionmaking related to public policies and private initiatives in order to promote the reduction of FLW levels, generating economic, social and environmental gains. It is also suggested that further studies should be encouraged in order to elucidate the relationship between commercial food transactions at a global level with food loss, assuming the hypothesis that commercial food shipments to more distant buyers and with an inefficient logistics infrastructure is possibly associated with higher levels of food loss.

\section{CONCLUSION}

The purpose of this study was to analyze the association between logistic performance, domestic food prices, food loss, diet diversification, depth of food deficit, and the prevalence of undernourishment worldwide. Considering these variables, evidence shows that food price is the factor that most impacts the prevalence of undernourishment, severely affecting diet diversification and depth of food deficit worldwide. Food price reduction should be a priority for governments worldwide in order to promote food security and extinguish undernourishment. It becomes clear there is a necessity of an improved and efficient global food system, capable of reducing food prices and delivering improved nutrition and health for world populations afflicted by undernourishment.

Despite the fact that logistic performance and food loss have a lower impact level than domestic food price on the prevalence of undernourishment in the countries analyzed, this study argues that inefficient logistics performance and high levels of food loss at global level negatively influence the conditions for promoting food security. Poor logistics performance and increasing food loss affect the conditions for adequately promoting food supply to the most vulnerable populations and affect the dynamics of food prices worldwide.

The study concludes that the eradication of hunger and the promotion of sustainable production and consumption must inevitably permeate the improvement of the logistics infrastructure and better regulation of food prices on a global scale, in order to drastically reduce the levels of food waste. In this way, it will be possible to promote in a better way the conditions necessary to guarantee security for the people of the world. This study also concludes that the promotion of food security and sustainable development objectives related to the eradication of hunger depend heavily on an improvement in the efficiency of food distribution in the global food systems. Therefore, efforts to be promoted by both the public and private sectors to reduce levels of food waste worldwide, thus promoting better conditions for food security, reducing environmental impacts and reducing waste of natural resources involved in the process of food production is urgently needed.

\section{REFERÊNCIAS}

Abbade, E. B. (2017). Availability, access and utilization identifying the main fragilities for promoting food security in developing countries. World Journal of Science Technology and Sustainable Development, 14(4), 322-335.

Abbade, E. B. (2018). The relationships between obesity-increasing risk factors for public health, environmental impacts, and health expenditures worldwide. Management of Environmental Quality: An International Journal.

Al-Ansari, T., Korre, A., Nie, Z., \& Shah, N. (2017). Integration of greenhouse gas control technologies within the energy, water and food nexus to enhance the environmental performance of food production systems. Journal of Cleaner Production, 162, 1592-1606. 
Aschemann-Witzel, J., Jensen, J. H., Jensen, M. H., \& Kulikovskaja, V. (2017). Consumer behaviour towards price-reduced suboptimal foods in the supermarket and the relation to food waste in households. Appetite, 116, 246-258.

Augustin, M. A., Riley, M., Stockmann, R., Bennett, L., Kahl, A., Lockett, T., Osmond, M., Sanguansri, P., Stonehouse, W., Zajac, I., \& Cobiac, L. (2016). Role of food processing in food and nutrition security. Trends in Food Science \& Technology, 56, 115-125.

Babu, S., Gajanan, S. N., \& Sanyal, P. (2014). Food security, poverty and nutrition policy analysis: Statistical methods and applications. Academic Press.

Bacenetti, J., Cavaliere, A., Falcone, G., Giovenzana, V., Banterle, A., \& Guidetti, R. (2018). Shelf life extension as solution for environmental impact mitigation: a case study for bakery products. Science of The Total Environment, 627, 997-1007.

Barrett, C. B. (2010). Measuring food insecurity. Science, 327(5967), 825-828.

Butcher, L. M., Ryan, M. M., O’Sullivan, T. A., Lo, J., \& Devine, A. (2018). What drives food insecurity in Western Australia? How the perceptions of people at risk differ to those of stakeholders. Nutrients, 10(8), 1059.

Buzby, J. C., \& Hyman, J. (2012). Total and per capita value of food loss in the United States. Food Policy, 37(5), 561-570.

Capone, R., Bilali, H. E., Debs, P., Cardone, G., \& Driouech, N. (2014). Food economic accessibility and affordability in the mediterranean region: an exploratory assessment at micro and macro levels. Journal of Food Security, 2(1), 1-12.

Cornia, G. A., Deotti, L., \& Sassi, M. (2016). Sources of food price volatility and child malnutrition in Niger and Malawi. Food Policy, 60, 20-30.

Corrado, S., Ardente, F., Sala, S., \& Saouter, E. (2017). Modelling of food loss within life cycle assessment: From current practice towards a systematisation. Towards Eco-Efficient Agriculture and Food Systems: Selected Papers Addressing the Global Challenges for Food Systems, Including Those Presented at the Conference "LCA for Feeding the Planet and Energy for Life" (6-8 October 2015, Stresa \& Milan Expo, Italy), 140, 847-859.

De Schutter, O. (2010). Report submitted by the Special Rapporteur on the right to food, Olivier De Schutter, United Nations Human Rights Council. 16th Session, Agenda Item, 3.

Delisle, H., \& Batal, M. (2016). The double burden of malnutrition associated with poverty. The Lancet, 387(10037), 2504-2505.

Dimitri, C., Oberholtzer, L., \& Pressman, A. (2016). Urban agriculture: connecting producers with consumers. British Food Journal, 118(3)

FAO. (2001). Food balance sheets: a handbook. Rome: Food and Agriculture Organization.

FAO. (2008). An introduction to the basic concepts of food security. Food Security Information for Action. Practical Guides.

FAO. (2011). Global food losses and food waste-Extent, causes and prevention. Save Food: An Initiative on Food Loss and Waste Reduction.

FAO. (2018a). Faostat. http://www.fao.org/faostat/en/\#data

FAO. (2018b). Sofi 2018-The State of Food Security and Nutrition in the World. Www.Fao.Org. http://www.fao.org/state-of-food-security-nutrition/en/ 
Food price, losses and logistics affecting diet diversification and food security

FAO. (2019). 2.1.1 Prevalence of undernourishment | Sustainable Development Goals | Food and Agriculture Organization of the United Nations.

FAO. (2020). Faostat: Food and agriculture data. http://www.fao.org/faostat/en/\#data

Garcia-Herrero, I., Hoehn, D., Margallo, M., Laso, J., Bala, A., Batlle-Bayer, L., Fullana, P., Vazquez-Rowe, I., Gonzalez, M. J., Durá, M. J., Sarabia, C., Abajas, R., Amo-Setien, F. J.,

Quiñones, A., Irabien, A., \& Aldaco, R. (2018). On the estimation of potential food waste reduction to support sustainable production and consumption policies. Food Policy, 80, 24-38.

GFSI. (2019). The Global Food Security Index.

Gustafsson, J., Cederberg, C., Sonesson, U., \& Emanuelsson, A. (2013). The methodology of the FAO study: Global Food Losses and Food Waste-extent, causes and prevention"-FAO, 2011. SIK Institutet för livsmedel och bioteknik.

Gustavsson, J., Cederberg, C., Sonesson, U., Van Otterdijk, R., \& Meybeck, A. (2011). Global food losses and food waste. FAO Rome.

Gutierrez, M. M., Meleddu, M., \& Piga, A. (2017). Food losses, shelf life extension and environmental impact of a packaged cheesecake: A life cycle assessment. Food Research International, 91, 124-132.

Hair, J. F., Anderson, R. E., Tatham, R. L., \& Black, W. C. (1995). Multivariate Data Analysis. Ingram, J. (2011). A food systems approach to researching food security and its interactions with global environmental change. Food Security, 3(4), 417-431.

Irani, Z., Sharif, A. M., Lee, H., Aktas, E., Topaloğlu, Z., van’t Wout, T., \& Huda, S. (2018). Managing food security through food waste and loss: Small data to big data. Computers \& Operations Research, 98, 367-383.

Jedermann, R., Nicometo, M., Uysal, I., \& Lang, W. (2014). Reducing food losses by intelligent food logistics. The Royal Society Publishing.

Jin, Y., Chen, T., Chen, X., \& Yu, Z. (2015). Life-cycle assessment of energy consumption and environmental impact of an integrated food waste-based biogas plant. Applied Energy, 151, 227236.

Johnson, L. K., Dunning, R. D., Gunter, C. C., Dara Bloom, J., Boyette, M. D., \& Creamer, N. G. (2018). Field measurement in vegetable crops indicates need for reevaluation of on-farm food loss estimates in North America. Agricultural Systems, 167, 136-142.

Kennedy, G. L., Pedro, M. R., Seghieri, C., Nantel, G., \& Brouwer, I. (2007). Dietary diversity score is a useful indicator of micronutrient intake in non-breast-feeding filipino children. The Journal of Nutrition, 137(2), 472-477.

Kibler, K. M., Reinhart, D., Hawkins, C., Motlagh, A. M., \& Wright, J. (2018). Food waste and the food-energy-water nexus: a review of food waste management alternatives. Waste Management, $74,52-62$.

Kummu, M., de Moel, H., Porkka, M., Siebert, S., Varis, O., \& Ward, P. J. (2012). Lost food, wasted resources: global food supply chain losses and their impacts on freshwater, cropland, and fertiliser use. Science of the Total Environment, 438, 477-489. Scopus.

Liljestrand, K. (2017). Logistics solutions for reducing food waste. International Journal of Physical Distribution \& Logistics Management, 47(4), 318-339. 
Lipinski, B., Hanson, C., Lomax, J., Kitinoja, L., Waite, R., \& Searchinger, T. (2013). Reducing food loss and waste. World Resources Institute Working Paper, June.

Macdiarmid, J. I., Douglas, F., \& Campbell, J. (2016). Eating like there's no tomorrow: Public awareness of the environmental impact of food and reluctance to eat less meat as part of a sustainable diet. Appetite, 96, 487-493.

Mason, P., Lang, T., \& Lang, T. (2017). Sustainable diets: how ecological nutrition can transform consumption and the food system. Routledge.

M'Kaibi, F. K., Steyn, N. P., Ochola, S. A., \& Du Plessis, L. (2017). The relationship between agricultural biodiversity, dietary diversity, household food security, and stunting of children in rural Kenya. Food Science \& Nutrition, 5(2), 243-254.

Nair, M. K., Augustine, L. F., \& Konapur, A. (2016). Food-based interventions to modify diet quality and diversity to address multiple micronutrient deficiency. Frontiers in Public Health, 3.

Nogeire-McRae, T., Ryan, E. P., Jablonski, B. B. R., Carolan, M., Arathi, H. S., Brown, C. S., Saki, H. H., McKeen, S., Lapansky, E., \& Schipanski, M. E. (2018). The Role of Urban Agriculture in a Secure, Healthy, and Sustainable Food System. BioScience, 68(10), 748-759.

O'Connor, N., Farag, K., \& Baines, R. (2016). What is food poverty? A conceptual framework. British Food Journal.

Papargyropoulou, E., Lozano, R., K. Steinberger, J., Wright, N., \& Ujang, Z. bin. (2014). The food waste hierarchy as a framework for the management of food surplus and food waste. Journal of Cleaner Production, 76, 106-115.

Parfitt, J., Barthel, M., \& Macnaughton, S. (2010). Food waste within food supply chains: Quantification and potential for change to 2050. Philosophical Transactions of the Royal Society B: Biological Sciences, 365(1554), 3065-3081.

Porpino, G., Parente, J., \& Wansink, B. (2015). Food waste paradox: Antecedents of food disposal in low income households. International Journal of Consumer Studies, 39(6), 619-629.

Poulsen, M. N., McNab, P. R., Clayton, M. L., \& Neff, R. A. (2015). A systematic review of urban agriculture and food security impacts in low-income countries. Food Policy, 55, 131-146.

Romeo, A., Meerman, J., Demeke, M., Scognamillo, A., \& Asfaw, S. (2016). Linking farm diversification to household diet diversification: evidence from a sample of Kenyan ultra-poor farmers. Food Security, 8(6), 1069-1085.

Sagar, N. A., Pareek, S., Sharma, S., Yahia, E. M., \& Lobo, M. G. (2018). Fruit and vegetable waste: bioactive compounds, their extraction, and possible utilization. Comprehensive Reviews in Food Science and Food Safety, 17(3), 512-531.

Sandell, M., Mikkelsen, B. E., Lyytikäinen, A., Ojansivu, P., Hoppu, U., Hillgrén, A., \& Lagström, H. (2016). Future for food education of children. Futures, 83, 15-23.

Sanyé-Mengual, E., Martinez-Blanco, J., Finkbeiner, M., Cerdà, M., Camargo, M., Ometto, A. R., Velásquez, L. S., Villada, G., Niza, S., Pina, A., Ferreira, G., Oliver-Solà, J., Montero, J. I., \& Rieradevall, J. (2018). Urban horticulture in retail parks: Environmental assessment of the potential implementation of rooftop greenhouses in European and South American cities. Journal of Cleaner Production, 172, 3081-3091.

Schott, A. B. S., \& Andersson, T. (2015). Food waste minimization from a life-cycle perspective. Journal of Environmental Management, 147, 219-226. 
Food price, losses and logistics affecting diet diversification and food security

Sen, A. (1981). Ingredients of famine analysis: availability and entitlements. The Quarterly Journal of Economics, 96(3), 433-464.

Spada, A., Conte, A., \& Del Nobile, M. A. (2018). The influence of shelf life on food waste: A model-based approach by empirical market evidence. Journal of Cleaner Production, 172, 3410 3414.

Steyn, N. P., Nel, J. H., Nantel, G., Kennedy, G., \& Labadarios, D. (2006). Food variety and dietary diversity scores in children: Are they good indicators of dietary adequacy? Public Health Nutrition, 9(5), 644-650.

Tabachnick, B. G., Fidell, L. S., \& Ullman, J. B. (2007). Using multivariate statistics, 5. Pearson Boston, MA.

Thorne-Lyman, A. L., Valpiani, N., Sun, K., Semba, R. D., Klotz, C. L., Kraemer, K., Akhter, N., de Pee, S., Moench-Pfanner, R., Sari, M., \& Bloem, M. W. (2010). Household dietary diversity and food expenditures are closely linked in Rural Bangladesh, Increasing the Risk of Malnutrition Due to the Financial Crisis. The Journal of Nutrition, 140(1), 182S-188S.

Thyberg, K. L., \& Tonjes, D. J. (2016). Drivers of food waste and their implications for sustainable policy development. Resources, Conservation and Recycling, 106, 110-123.

Vellakkal, S., Fledderjohann, J., Basu, S., Agrawal, S., Ebrahim, S., Campbell, O., Doyle, P., \& Stuckler, D. (2015). Food price spikes are associated with increased malnutrition among children in Andhra Pradesh, India. The Journal of Nutrition, 145(8), 1942-1949.

Webb, P., Coates, J., Frongillo, E. A., Rogers, B. L., Swindale, A., \& Bilinsky, P. (2006). Measuring household food insecurity: why it's so important and yet so difficult to do. Journal of Nutrition, 136(5), 1404S-1408S.

WHO. (2017). Guideline: assessing and managing children at primary health-care facilities to prevent overweight and obesity in the context of the double burden of malnutrition. World Health Organization.

WHO. (2018). World Health Organization.

World Bank. (2019). Logistics performance index.

Zezza, A., \& Tasciotti, L. (2010). Urban agriculture, poverty, and food security: empirical evidence from a sample of developing countries. Food Policy, 35(4), 265-273.

Zhang, C., Chen, X., Li, Y., Ding, W., \& Fu, G. (2018). Water-energy-food nexus: concepts, questions and methodologies. Journal of Cleaner Production, 195, 625-639.

RGSA adota a Licença de Atribuição CC BY do Creative Commons (https://creativecommons.org/licenses/by/4.0/). 